\title{
UPAYA PEMBENTUKAN WARGA NEGARA YANG BAIK DAN TANTANGAN YANG DIHADAPI OLEH PARA GURU PKN PESERTA SM3T 2015
}

\author{
Suyato, Mukhamad Murdiono, Budi Mulyono, Iqbal Arpannudin \\ Jurusan Pendidikan Kewarganegaraan dan Hukum Universitas Negeri Yogyakarta \\ suyato@uny.ac.id
}

\begin{abstract}
The research was an explorative research deploying interview and questionnaire as collecting data methods. Collected data was analyzed descriptive qualitatively. The research found that (1) although respondents have different conceptions of good citizens, they have shared view on main features of good citizen, namely caring others, responsibility, independence, democratic, critical, and simple life; (2) almost all of them have chosen lecturing as instructional method to develop good citizen; (3) they have found both internal and external obstacles in dealing with their efforts, such as teachers themselves and students and the lack of infrastructures of schools; and (4) many efforts were deployed, one of them was of seduction their colleagues to work professionally. They believed that it was not thought but caught by which a good citizen could be developed. They were ready to be examples.
\end{abstract}

Keywords: good citizen, SM3T, civic education

\section{PENDAHULUAN}

Pembentukan warga negara yang baik menjadi salah satu misi utama pendidikan nasional Indonesia. Salah satu mata pelajaran yang juga mengemban misi tersebut adalah Pendidikan Pancasila dan Kewarganegaraan (PPKn). PPKn persekolahan diberikan mulai dari jenjang pendidikan dasar sampai jenjang sekolah menengah atas. Dengan demikian, guru PPKn menjadi tulang punggung bagi tercapainya misi tersebut. Dengan kata lain, profesionalitas para guru PPKn merupakan salah satu faktor keberhasilan misi tersebut. Namun demikian, terdapat perbedaan baik menyangkut masalah konseptual maupun praktis terkait dengan konsep kewarganegaraan termasuk upaya untuk membentuknya melalui lembaga formal bernama sekolah.

Konsep tentang warga negara yang baik dan upaya untuk mewujudkannya telah menjadi bahan perdebatan yang cukup panjang di antara para pakar Pendidikan
Kewarganegaraan (PKn). Secara garis besar, ada tiga dimensi yakni "knowledge and understanding about becoming informed citizens, developing skills of inquiry and approach, developing skills of participation and responsible action" (Bîrzéa, 2000; Crick, 1998; Davies, Shirley, \& C.Riley, 2003; Johnson \& Morris, 2010; J. Kahne \& Westheimer, 2003; Print \& Lange, 2012; Veldhuis, 1997; Veugelers, 2007).

Sosok warga negara yang baik merupakan hasil dari beragam aspirasi kekuatan sosial politik yang ada di dalam masyarakat. Dengan kata lain, di dalam negara dengan sistem politik liberal tentu memiliki konsepsi yang berbeda tentang sosok warga negara ideal dari negara dengan sistem politik komunitarian. Demikian juga dengan negara Indonesia yang memiliki corak sistem politik yang lebih bersifat komunitarian tentu memiliki konsepsi tentang sosok warga negara yang baik khas Indonesia.

Upaya untuk memahami konsep warga negara yang baik telah banyak dilakukan oleh 
para ahli. Oleh karena itu, konsepsi tentang warga negara yang baik sangat beragam. Selain itu, perbedaan konsep tentang warga negara yang baik juga disebabkan karena adanya perbedaan konsepsi tentang tatanan bermasyarakat dan bernegara yang dianggap baik. Bagi kaum konservatif yang mengutamakan keteraturan, kenyamanan, dan kedamaian, tentu saja berbeda dengan kaum progresif yang menginginkan kemajuan, tantangan, dan inovasi. Kelompok yang pertama tentu lebih menyukai sosok warga negara yang disiplin, mengikuti atau mematuhi segala peraturan dan norma yang berlaku, sedangkan kelompok kedua merasa tidak nyaman dengan konsep warga negara yang baik seperti itu, karena hanya akan melestarikan status quo. Kelompok progresif lebih menginginkan warga negara yang baik, yang bersifat critical. Kelompok ketiga, menginginkan sosok warga negara yang baik bukan hanya yang disiplin, kritis, tetapi juga yang mandiri atau otonom. Para pendukung liberalisme, warga negara yang baik adalah yang bisa menjadi diri sendiri. Sedangkan para pendukung Pancasila, tentu juga memiliki konsepsi yang berbeda tentang ciriciri warga negara yang baik.

Proyek penelitian yang dilakukan dengan nama Citizenship, Involvement, Democracy (CID) dan European Social Survey (ESS) menemukan gambaran sosok warga negara yang baik di kalangan bangsa Eropa, mencakup: form independent opinion (didukung 70\%), always obey laws/regulation (65\%), vote in elections (61\%), support people worse off (58\%), be active in voluntary organizations (27\%), be active in politics (10\%) (Deth, 2013, p. 11). Gambaran serupa juga disimpulkan oleh Denters and van der Kolk (Deth, 2013) bahwa “...the general statement of a good citizen being one who is active in politics is, on average, least supported in all European countries". Keengganan warga negara Eropa untuk meletakkan pentingnya partisipasi baik politik maupun sosial sebagai indikator warga negara yang baik juga ditemukan dalam beberapa studi (Theiss-morse \& Hibbing, 2005).

Perbedaan konsepsi tentang kewarganegaraan akan berimplikasi pada perbedaan konsepsi tentang sosok warga negara yang baik. Demikian juga selanjutnya, perbedaan konsepsi tentang karakteristik warga negara yang baik akan berakibat terjadinya perbedaan dalam upaya untuk mewujudkannya. Namun demikian, upaya untuk memahami secara serius berupa penelitian dengan fokus permasalahan pada konsepsi para guru tentang sosok warga negara yang baik termasuk upaya pembentukannya, baik melalui kegiatan pembelajaran PPKn di ruang kelas maupun di luar ruang kelas, belum banyak dilakukan. Dengan logika pemikiran seperti ini, perlu kiranya dilakukan penelitian untuk mengetahui konsepsi para guru PPKn tentang sosok warga negara yang baik dan upaya pembentukannya.

Beberapa penelitian menunjukkan kesimpulan secara umum, sebagaimana dirangkum Print dan Lange (2012) sebagai berikut. Pertama, penelitian menunjukkan bahwa participatory pedagogy di sekolah agak lemah. Pembelajaran lebih ditandai oleh textbooks, rote learning, and nonparticipatory, non-critical strategies, serta tanpa persiapan guru yang memadai. Kedua, penelitian substansi; menunjukkan bahwa pendekatan partisipatif seperti class voting, group inquiry, simulations, fieldwork dan cooperative learning, lebih cenderung untuk membuat siswa terlibat dalam belajar dengan 
cara mengalami langsung serta aspek-aspek nilai-nilai dan praktik-praktik demokrasi dibanding dengan pendekatan yang lain. Ketiga, khusus penelitian di Inggris menunjukkan bahwa engaged pedagogy dapat meningkatkan belajar dan prestasi siswa, khususnya ketika ditandai dengan pedagogi yang facilitative dan conversational. Lebih lanjut bahwa pedagogi semacam itu dapat meningkatkan partisipasi siswa, kemampuan berkomunikasi siswa, dan memberdayakan siswa untuk lebih berpartisipasi. Keempat, diskusi kritis secara terbuka, informed, dan meaningful serta kritis dengan para guru yang tidak memihak berpengaruh secara sangat signifikan dalam partisipasi siswa. Kelima, banyak sekali faktor-faktor lain yang bisa memengaruhi secara signifikan hasil belajar yang diperoleh siswa di sekolah sebagaimana telah ditunjukkan oleh banyak penelitian. Variabel-variabel yang dimaksud misalnya latar belakang pendidikan dan pengetahuan guru, sumber daya yang tersedia, iklim kelas, prosedur penilaian, iklim sekolah, kesempatan untuk mempelajari kurikulum, yang kesemuanya kemungkinan akan berpengaruh terhadap pengetahuan, pemahaman, sikap, keterampilan dan disposisi siswa. Pendekatan-pendekatan semacam ini memberi peluang kepada siswa untuk belajar tentang politik dan membangun keterlibatan siswa dalam kehidupan berbangsa dan bernegara.

Dalam praktik persekolahan, khususnya di lokasi yang menjadi sasaran penempatan peserta SM3T, guru merupakan ujung tombak dalam usaha mewujudkan misi PKn, yang antara lain adalah upaya pembentukan warga negara yang baik. Untuk mewujudkan misi tersebut, diperlukan pendekatan-pendekatan yang sesuai. Secara garis besar, dikenal tiga pendekatan dalam pendidikan kewarganegaraan, yaitu transmission, individualized, dan critical-democratic (Veugelers, 2011) Sedangkan ahli lain membedakan antara interaksi, transaksi, dan transformasi. Ada pembedaan yang, dalam arti pendekatan yang digunakan, misalnya directive dan constructive approach. Menurut Miller (2007), terdapat tiga pendekatan utama dalam pembelajaran, yaitu transmisi, transaksi, dan transformasi. Ketiga pendekatan ini berangkat dari asumsi yang berbeda, baik menyangkut pandangannya tentang siswa, guru, dan pembelajaran. Pendekatan transmisi memandang siswa sebagai objek, ibarat botol kosong, sehingga tugas guru adalah mengisinya. Dengan demikian hakikat pembelajar identik dengan pengalihan atau transmisi, baik menyangkut pengetahuan, sikap, maupun keterampilan. Pendekatan transaksi memandang siswa sebagai subjek yang perlu diajak bersama guru menentukan, baik materi, tujuan, maupun pembelajaran atau kegiatan yang akan dilakukan bersama dengan guru. Oleh karena itu, hakikat pembelajaran adalah transaksi antara guru dan siswa. Pendekatan terakhir, transformasi, berangkat dari asumsi bahwa hakikat belajar adalah terjadinya transformasi pada diri siswa. Dengan kata lain, tujuan dari pendekatan transformatif adalah terjadinya perubahan secara menyeluruh pada diri siswa sebagai pribadi yang unik.

Kondisi di lapangan terdapat perbedaan tentang konsep warga negara yang baik dan upaya pembentukannya baik melalui pembelajaran di kelas maupun kegiatan dan pembiasaan di luar kelas, perlu kiranya diadakan penelitian awal berupa studi eksplorasi tentang konsep warga negara yang baik, upaya yang dilakukan, serta hambatan yang dihadapi para guru tersebut. 


\section{METODE}

Penelitian ini merupakan penelitian deskriptif eksploratif. Pendekatan yang digunakan adalah pendekatan kualitatif. Penelitian ini berusaha mendeskripsikan konsep warga negara yang baik menurut para guru peserta SM3T yang mengikuti PPG di UNY tahun 2016. Selanjutnya dideskripsikan tentang upaya yang mereka lakukan di dalam pembelajaran PPKn di kelas dalam rangka pembentukan warga negara yang baik, hambatan yang mereka hadapi serta upaya yang mereka lakukan untuk mengatasi hambatan tersebut. Data yang diperoleh kemudian dianalisis secara kualitatif. Data kuantitatif juga digunakan untuk mendukung pernyataan yang bersifat kualitatif.

Data yang terkumpul, baik berupa persepsi para guru peserta SM3T tentang sosok warga negara yang baik, upaya yang mereka lakukan, hambatan serta upaya untuk mengatasi hambatan, dianalisis secara kualitatif dengan langkah-langkah sebagai berikut. Langkah pertama adalah reduksi data. Tidak semua data yang terkumpul digunakan untuk dianalisis tetapi hanya dipilih yang relevan dengan tujuan penelitian. Langkah kedua adalah unifikasi atau kategorisasi. Data dikategorikan sesuai dengan tema yang berkembang di lapangan.
Langkah selanjutnya display penyajian data. Pengorganisasian dan penyajian data dilakukan berdasarkan pertanyaan penelitian. Langkah terakhir berupa penarikan kesimpulan.

\section{HASIL DAN PEMBAHASAN \\ HASIL PENELITIAN}

\section{Deskripsi Persepsi tentang Karakteristik Utama Warga Negara yang Baik.}

Persepsi para guru peserta SM3T yang menjadi subjek dalam penelitian tentang sosok warga negara yang baik berbeda-beda tetapi memiliki beberapa kesamaan. Ketika diminta mengurutkan tiga teratas prioritas pengembangan dari daftar ciri-ciri warga negara yang baik yang meliputi peduli sesama, bertanggung jawab, mandiri, demokratis, dan kritis, ternyata sebanyak 18 dari 20 (90\%) menyatakan kepedulian terhadap sesama merupakan prioritas utama. Sedangkan sikap dan sifat kritis menduduki uritan terakhir di dalam prioritas pengembangannya. Ada satu guru yang menyebutkan ciri di luar daftar yang diberikan peneliti, yaitu ciri atau sifat sederhana yang juga perlu dikembangkan. Data selengkapnya dapat dibaca pada tabel berikut ini. 
Tabel 1 Perspektif Karakteristik Utama Warga Negara yang Baik

\begin{tabular}{clccc}
\hline No. $\begin{array}{c}\text { Konsep Warga Negara } \\
\text { Priong Baik yang Menjadi }\end{array}$ & $\begin{array}{c}\text { Jumlah } \\
\text { Pendukung }\end{array}$ & $\begin{array}{c}\text { Jumlah } \\
\text { Pendukung } \\
(\%)\end{array}$ & $\begin{array}{c}\text { Keterangan } \\
\text { (Responden } \\
\text { diminta untuk } \\
\text { memilih tiga } \\
\text { teratas) }\end{array}$ \\
\hline 1. & Peduli Sesama & 18 & 90 & \\
2. Bertanggung Jawab & 14 & 75 & \\
3. Mandiri & 12 & 60 & \\
4. Demokratis & 10 & 50 & Mencantumkan \\
5. Kritis & 5 & 25 & Sederhana. \\
6. Lain-Lain (tidak & 1 & 05 & \\
& termasuk ke dalam lima & & &
\end{tabular}

Sumber: Data diolah peneliti, 2016

\section{Deskripsi tentang karakteristik yang} perlu dimiliki untuk menjadi warga negara yang baik.

Peneliti juga mengungkap data tentang urgensi pengembangan ciri-ciri warga negara yang baik di lokasi tempat mereka mengajar selama mengikuti program SM3T. Instrumen yang kami gunakan merupakan elaborasi dari keenam ciri warga negara yang baik, sebagaimana dikemukakan di muka. Berdasarkan jawaban atas angket yang peneliti bagikan dapat dirangkum data tentang karakteristik sebagai prasyarat untuk menjadi warga negara yang baik yang perlu dikembangkan sebagai berikut.

Tabel 2 Elaborasi Karakteristik Menjadi Warga Negara Yang Baik

\begin{tabular}{clccc}
\hline No & \multicolumn{1}{c}{ Karakteristik Kewarganegaraan } & $\begin{array}{c}\text { Sangat } \\
\text { Penting }\end{array}$ & Penting & $\begin{array}{c}\text { Kurang } \\
\text { Penting }\end{array}$ \\
\hline 1 & Pengetahuan tentang peristiwa kenegaraan terkini & 1 & 2 & 17 \\
2 & Partisipasi dalam kehidupan sekolah/masyarakat & 18 & 2 & 0 \\
3 & Menjalankan tugas yang diberikan & 10 & 10 & 0 \\
4 & Kepedulian terhadap kehidupan orang lain. & 9 & 11 & 0 \\
5 & Perilaku etis dan bermoral. & 8 & 12 & 0 \\
6 & Taat kepada pemimpin adat dan/atau formal. & 17 & 3 & 0 \\
7 & Keberanian untuk memberikan gagasan & 0 & 5 & 15 \\
8 & Kemampuan untuk membuat keputusan secara bijak & 3 & 12 & 5 \\
9 & Pengetahuan tentang pemerintahan. & 0 & 3 & 17 \\
10 & Patriotisme/cinta tanah air & 4 & 16 & 0 \\
11 & Memenuhi tanggung jawab di dalam keluarga & 5 & 14 & 1 \\
12 & Pengetahuan tentang ekonomi dunia. & 0 & 0 & 20 \\
13 & Toleransi di dalam masyarakat yang majemuk. & 5 & 15 & 0 \\
\hline
\end{tabular}

Sumber: Data diolah peneliti, 2016

Dari data tersebut dapat disimpulkan bahwa yang paling mendapat dukungan sebagai prioritas utama pengembangan atau yang 
sangat penting dikembangkan, tiga besar secara berturut-turut adalah partisipasi di dalam kehidupan sekolah/masyarakat, ketaatan kepada tokoh adat/pemimpin, dan pemenuhan tugas yang diberikan. Sedangkan tiga terbawah dalam hal skala prioritas pengembangannya adalah pengetahuan tentang ekonomi dunia, pengetahuan tentang pemerintah, dan pengetahuan tentang peristiwa kenegaraan kontemporer.

\section{Deskripsi Penggunaan Metode Mengajar yang Paling Sering Digunakan.}

Metode mengajar yang digunakan oleh para guru selama mengajar sebagai peserta SM 3T beragam, tetapi semuanya menyatakan bahwa metode ceramah merupakan metode yang paling sering mereka gunakan. Secara lengkap, metodemetode yang mereka gunakan dapat dibaca pada tabel berikut ini.

Tabel 3 Penggunaan Metode oleh para Guru

\begin{tabular}{lll}
\hline No. & \multicolumn{1}{c}{ Nama } & \multicolumn{1}{c}{ Metode } \\
\hline 1. & Selfiane F Lumowa, S.Pd. & Calistung (SD), ceramah. \\
2. & Sakriana, S.Pd. & Tematik, ceramah. \\
3. & Sri Hartini, S.Pd. & Ceramah, praktik langsung, tutor sebaya. \\
4. & Siti Hadijah, S.Pd. & Calistung (SD). \\
5. & Ika Listanti, S.Pd. & Ceramah, Diskusi, dan Presentasi Kelompok. \\
6. & Desi Ariani, S.Pd. & Ceramah. \\
7. & Joan Bugis, S.Pd. & Ceramah. \\
8. & Utik Seftia Ardiana, S.Pd. & Ceramah. \\
9. & Sudarmini, S.Pd. & Ceramah. \\
10. & Nocry L. Rindengan, S.Pd. & Pendekatan Demokratis, Otoriter, Praktik \\
& & Langsung \\
11. & I Made Kembar Arta, S.Pd. & Ceramah. \\
12. & Sinta Kurnia Sari, S.Pd. & Ceramah dan Diskusi. \\
13. & M. Fatkhul Damanhury, & Ceramah, Mind Mapping, Calistung (SD) \\
& S.Pd. & \\
14. & Wahyudin, S.Pd. & Ceramah \\
15. & Radiansah, S.Pd. & Ceramah, diskusi, jalan-jalan \\
16. & Lysa Hapsari, S.Pd. & Ceramah, kuis. \\
17. & A. Zhulkifli A.S., S.Pd. & Ceramah \\
18. & Dwi Hari Saputro, S.Pd. & Ceramah \\
19. & Kristina Dwi Hastutik, S.Pd. & Ceramah \\
20. & Rubiati, S.Pd. & Ceramah \\
\hline
\end{tabular}

Sumber: Data diolah peneliti, 2016

Apabila data tentang persepsi tentang sosok warga negara yang baik dan metode yang digunakan para guru peserta
SM3T disandingkan maka dapat diperoleh gambaran, sebagaimana disajikan pada tabel berikut ini.

Tabel 4 Gabungan Persepsi tentang Warga Negara yang Baik dan Pilihan Metode Mengajar

\begin{tabular}{cccc}
\hline No & $\begin{array}{c}\text { Persepsi tentang Karakteristik } \\
\text { Warga Negara yang Baik }\end{array}$ & Pilihan Metode & Keterangan \\
\hline 1 & Peduli Sesama & Ceramah & \\
\hline
\end{tabular}




\begin{tabular}{|c|c|c|c|}
\hline No & $\begin{array}{l}\text { Persepsi tentang Karakteristik } \\
\text { Warga Negara yang Baik }\end{array}$ & Pilihan Metode & Keterangan \\
\hline 2 & Bertanggung Jawab & Ceramah & \\
\hline 3 & Mandiri & Ceramah & \\
\hline 4 & Demokratis & Ceramah & \\
\hline 5 & Kritis & Ceramah & \\
\hline 6 & $\begin{array}{l}\text { Lain-Lain (tidak termasuk ke } \\
\text { dalam lima kategori di atas) } \\
\text { Kesederhanaan }\end{array}$ & Ceramah & \\
\hline
\end{tabular}

Sumber: Data diolah peneliti, 2016

Dari data sebagaimana disajikan pada data di atas, maka dapat ditarik kesimpulan bahwa ternyata tidak ada pengaruhnya antara sosok warga negara yang baik atau prioritas pengembangan ciri-ciri warga negara yang baik terhadap pilihan metode mengajarnya. Namun demikian, bukan berarti para guru peserta tidak melakukan upaya dalam rangka pembentukan warga negara yang baik di luar kelas atau di luar cara mengajar mereka. Data tentang upaya yang mereka lakukan untuk membentuk warga negara yang baik dibahas pada bagian berikut ini.
4. Upaya yang Dilakukan untuk Membentuk Warga Negara yang Baik. Para guru peserta SM3T melakukan beragam upaya untuk membentuk warga negara yang baik sesuai dengan keyakinan mereka, baik di kelas lewat mata pelajaran yang mereka ajarkan, khususnya PPKn, maupun program pembiasaan di lingkungan sekolah serta di lingkungan masyarakat. Upaya yang mereka lakukan dalam rangka membentuk warga negara yang baik dapat disajikan dalam tabel berikut:

Tabel 5 Upaya Pembentukan Warga Negara yang Baik

\begin{tabular}{|c|c|c|c|c|}
\hline No. & Karakteristik & Di kelas & Di sekolah & Di Masyarakat \\
\hline 1 & Kepedulian & $\begin{array}{l}\text { Ceramah, contoh dari } \\
\text { guru }\end{array}$ & $\begin{array}{l}\text { Pembiasaan, } \\
\text { hidden } \\
\text { curriculum }\end{array}$ & $\begin{array}{l}\text { Les di } \\
\text { Asrama, } \\
\text { pembiasaan, }\end{array}$ \\
\hline 2 & $\begin{array}{l}\text { Tanggung } \\
\text { Jawab }\end{array}$ & Ceramah & $\begin{array}{l}\text { Pembiasaan, } \\
\text { keteladanan, } \\
\text { hidden }\end{array}$ & $\begin{array}{l}\text { Keteladanan, } \\
\text { Praktik } \\
\text { langsung }\end{array}$ \\
\hline 3 & Mandiri & $\begin{array}{l}\text { Ceramah, pemberian } \\
\text { tugas, pembiasaan. }\end{array}$ & $\begin{array}{l}\text { Pembiasaan, } \\
\text { keteladanan, } \\
\text { hidden }\end{array}$ & $\begin{array}{l}\text { Kunjungan ke } \\
\text { Asrama guru. }\end{array}$ \\
\hline 4 & Demokratis & $\begin{array}{l}\text { Ceramah, praktik } \\
\text { langsung, (misalnya } \\
\text { penentuan materi yang } \\
\text { akan diajarkan atau } \\
\text { kegiatan yang akan } \\
\text { dilakukan) }\end{array}$ & $\begin{array}{l}\text { Pembiasaan, } \\
\text { keteladanan, hidden } \\
\text { curriculum }\end{array}$ & $\begin{array}{l}\text { Praktik } \\
\text { langsung }\end{array}$ \\
\hline
\end{tabular}




\begin{tabular}{lllll}
\hline No. & Karakteristik & \multicolumn{1}{c}{ Di kelas } & \multicolumn{1}{c}{ Di sekolah } & Di Masyarakat \\
\hline 5. & Kritis & $\begin{array}{l}\text { Ceramah, praktik } \\
\text { langsung. }\end{array}$ & $\begin{array}{l}\text { Keteladanan, } \\
\text { hidden } \\
\text { curriculum }\end{array}$ & $\begin{array}{l}\text { Keteladanan } \\
\text { dalam hidup } \\
\text { sehari-hari }\end{array}$ \\
6. & Kesederhanaan & $\begin{array}{l}\text { Ceramah, keteladanan, } \\
\text { hidden curriculum }\end{array}$ & Pembiasaan & Keteladanan.
\end{tabular}

Sumber: Data diolah peneliti, 2016

5. Hambatan yang Dihadapi dalam Membentuk Warga Negara Yang Baik

Dalam upaya pembentukan warga negara yang baik, para guru peserta SM3T menghadapi sejumlah hambatan. Pertama, mereka dihadapkan pada kondisi sekolah dengan keterbatasan sumber daya manusia (jumlah guru yang minim), sarana prasarana (Ruang kelas, meja, kursi, papan tulis, buku paket), kultural (kebiasaan, mindset) yang belum kondusif untuk pengembangan karakteristik warga negara yang baik. Kedua, hambatan dari masyarakat.

Terjadi paradoks, di satu sisi mereka disambut bagaikan pahlawan, di sisi lain ternyata tidak diimbangi dengan dukungan budaya akan pentingnya pembentukan warga negara yang baik, dalam arti yang dituntut untuk mendukung kehidupan yang demokratis, mandiri dan kritis. Bahkan ada salah satu sekolah yang mendukung kepala sekolahnya untuk tetap tinggal di kota, sementara para guru secara bergantian mengunjungi kepala sekolah ke kota untuk mengomunikasikan segala sesuatu yang berkaitan dengan kegiatan sekolah. Alasan yang mereka kemukakan justru lebih efektif terkait dengan urusan birokrasi. Sedangkan hambatan dari diri pribadi, yang bersifat personal, baik dari para guru maupun para siswa, berupa doing business as usual (mengerjakan sesuatu seperti biasanya).

\section{Upaya yang Dilakukan}

Menyadari bahwa tidak mungkin mereka bisa mengatasi hambatan yang begitu besar, para guru peserta SM3T merangkul semua pemangku kepentingan untuk mencari solusi. Contoh nyata, dengan keberadaan para guru peserta SM3T, banyak guru PNS yang semula enggan datang ke sekolah (bahkan ada yang dua bulan tidak hadir), menjadi sering hadir di sekolah. Beberapa guru peserta SM3T bahkan harus mengajar rangkap kelas dan rangkap sekolah. Beberapa diantara mereka bahkan ada yang bahu-membahu dengan masyarakat untuk membuat ruang kelas agar kegiatan belajar mengajar menjadi kondusif.

\section{PEMBAHASAN}

Dari deskripsi data hasil penelitian di atas dapat dilakukan beberapa analisis sebagai berikut.

\section{Konsep Warga Negara yang Baik}

Semua subjek penelitian memiliki kesamaan persepsi tentang sosok atau karakteristik warga negara yang baik, yaitu dimilikinya kepedulian sosial. Hal ini barangkali disebabkan oleh sifat masyarakat kita yang komunal, bukan individualistik. Kalau pembahasan dikaitkan dengan tiga ranah bidang yang menjadi perhatian atau fokus 
pengembangan PKn, yaitu civic knowledge, civic skills, dan civic dispositions, dapat disimpulkan bahwa penekanan pengembangan komponen kewarganegaraan lebih pada komponen civic dispositions, disusul komponen skills, dan terakhir civic knowledge. Dengan kata lain, penekanannya lebih pada aspek-aspek praktis yang dibutuhkan dalam kehidupan sehari-hari. Sedangkan aspek pengetahuan kurang mendapat perhatian mengingat dalam praktik kehidupan sehari-hari masyarakat di daerah 3T bahkan banyak yang tidak menyadari akan "kehadiran negara" dalam kehidupan mereka.

\section{Pilihan Metode Mengajar}

Dari keduapuluh responden penelitian yang diminta untuk menuliskan metode mengajar yang paling sering mereka pilih ketika mengajar, semuanya menyebutkan metode ceramah, bahkan kebanyakan menyatakan sebagai satu-satunya metode yang mereka gunakan. Hanya ada lima responden yang menyebutkan metode lain, yaitu diskusi dan praktik. Dengan demikian dapat ditarik kesimpulan bahwa metode ceramah masih menjadi "idola" bagi para guru peserta SM3T.

Kelebihan yang ada pada metode ceramah, seperti murah dan mudah dilaksanakan merupakan pertimbangan ketika para guru memilih metode itu. Dengan kondisi sekolah yang masih jauh dari ideal, terutama sarana dan prasarana, peralatan atau media pembelajaran, guru praktis hanya mengandalkan metode ceramah. Hal ini disadari hampir oleh semua peserta. Salah satu responden bahkan menyatakan bahwa tugas utama mereka adalah mengajarkan membaca dan berhitung.

3. Hubungan antara Persepsi warga Negara yang Baik dan Pilihan Metode Mengajar

Dengan memperhatikan data tentang konsep warga negara yang baik dan pilihan metode mengajar yang disampaikan para guru peserta SM3T di atas, dapat disimpulkan bahwa tidak ada hubungan antara kedua variabel tersebut. Artinya, ketika guru memilih metode mengajar, mereka tidak mempertimbangkan tujuan pembelajaran. Bahkan sebagian dari mereka tidak memperhatikan lagi Standar Kompetensi, Kompetensi Dasar yang seharusnya menjadi pedoman mereka ketika merancang kegiatan belajar mengajar (KBM). Meskipun para guru menyadari akan kebermaknaan kehadiran mereka di lokasi penempatan atau penugasan sebagai peserta SM3T, mereka tidak bisa mengembangkan idealisme karena keterbatasan sarana dan prasarana. Justru yang mereka butuhkan dalam kondisi tersebut adalah strategi untuk memanfaatkan bahan-bahan yang bisa mendukung untuk terciptanya KBM.

4. Perspektif Teoretis Prasyarat Perilaku Demokratis

Fenomena pengalaman mengajar para guru peserta SM3T yang saat ini tengah mengikuti PPG di UNY bisa dikaji dari perspektif teoretis. Dalam hal ini kami akan membahas salah satu karakteristik yang harus dikembangkan untuk terciptanya warga negara yang baik, yaitu karakter demokratis. De Groot (2011, pp. 85-90), misalnya mengelaborasi lima prasyarat untuk terbentuknya sikap demokratis warga 
negara. Kelima prasyarat tersebut dapat dijelaskan sebagai berikut.

a. Dimensi 1: Kemampuan mengelaborasi pemahaman tentang demokrasi dan keberagaman. Pertamatama, perkembangan identitas kewarganegaraan demokratis seseorang dipengaruhi oleh keyakinan akan nilai-nilai yang dilekatkan terhadap demokrasi dan keberagaman dan interpretasi mereka terhadap konsep-konsep ini. Dalam rangka untuk mengembangkan sikap demokratis yang benar, seseorang perlu mengelaborasi pemahaman tentang nilai-nilai demokrasi dan keberagaman bagi kehidupan diri mereka sendiri maupun kebaikan bersama bagi masyarakat. Ini berarti bahwa mereka harus sadar bahwa demokrasi bukan hanya berkaitan dengan sistem politik dan pemerintahan tetapi juga a way of life. Ini juga mengisyaratkan perlunya diupayakan kondisi yang pase ketika mengapresiasikan keberagaman (Mouffe, 2005). Termasuk di dalam dimensi pertama ini antara lain: kemampuan merefleksikan tentang nilai-nilai pribadi mereka, pemosisian diri, dan keberagaman pribadi serta sensitivitas terhadap isu-isu keadilan sosial.

b. Dimensi 2: Kapasitas untuk berpartisipasi di dalam sebuah cara yang tercerahkan secara demokratis. Meskipun menjadi tercerahkan secara demokratis belum tentu berarti bahwa seseorang akan menjadi aktif terlibat dalam kehidupan bermasyarakat. Oleh karena itu dibutuhkan perasaan akan kemampuan diri untuk memberdayakan diri sendiri dan lingkungannya (internal and external efficacy). Terkait dengan ini, (J. Kahne \& Westheimer, 2003, p. 54) menyatakan bahwa dalam rangka untuk mengembangkan sikap demokratis, seseorang membutuhkan tiga C: Capacity, Commitment, and Connection. Menurut kedua ahli ini, efikasi internal mengacu pada perasaan bahwa seseorang mampu untuk mengubah benda atau kondisi, sedangkan efikasi eksternal mengacu pada keyakinan bahwa pemerintah atau lembaga akan menerima atau bersifat receptive terhadap kebutuhan warga negara.

c. Dimensi 3: Hubungan Aktif. Dimensi ketiga ini mengacu pada hubunganhubungan aktif. Dalam rangka untuk menumbuh-kembangkan hubungan aktif, seseorang memerlukan kemampuan untuk menjalin hubungan dan memiliki komitmen.

d. Dimensi 4: Keinginan untuk melakukan reformasi atau perubahan. Dimensi keempat ini berkaitan dengan keinginan untuk berubah. Jika seseorang tidak ingin melakukan investigasi atau penelaahan nilai-nilai, pandangan hidup, kebiasaan-kebiasaan mereka sendiri maupun orang lain, mereka tidak akan mampu sling membantu dalam rangka memberikan makna bagi perkembangan masyarakat dengan cara yang mendukung kehidupan yang lebih baik. Sebagaimana dikemukakan Ramadan (Ramadan, 2007), baik orang yang memandang dirinya sebagai faktor dominan maupun tidak, perlu mengembangkan sikap ini. 
e. Dimensi 5: Dialog. Dalam dimensi ini, pembahasan difokuskan pada kemampuan dan kemauan seseorang untuk melakukan dialog. Dialog mengisyaratkan kemauan seseorang untuk menghormati dan menerima pendapat atau visi orang lain dan yang memiliki kesadaran untuk mencapai kesepakatan atau pemahaman timbal balik. Dua sifat yang harus dimiliki yaitu empathy dan kompetensi dialogis.

Dari perspektif teori yang dikemukakan di atas, maka dapat ditarik kesimpulan bahwa ada lima dimensi dari sikap positif terhadap demokrasi dan keberagaman, yang bisa dijadikan pedoman para guru ketika berusaha membentuk warga negara yang demokratis, yaitu: (1) elaborasi pemahaman akan nilainilai demokrasi dan keberagaman (refleksi dan sensitivitas moral); (2) kapasitas (efikasi internal dan eksternal); (3) hubunganhubungan aktif (komitmen dan koneksi); (4) Kemauan transformasi (bersifat terbuka terhadap kritik ); dan (5) kemampuan berdialog ( empati dan kompetensi dialogis). Kelima sikap positif tersebut sebenarnya sudah dipraktikkan di dalam budaya masyarakat Indonesia hanya tidak secara tegas dinyatakan bahwa sikap tersebut adalah sikap positif terhadap demokrasi.

Proses pembentukan warga negara yang baik ternyata tidak bisa dilakukan dengan pendekatan kebijakan yang bersifat top down (dari Pemerintah Pusat), tetapi harus bersifat bottom up (dari bawah-akar rumput). Dengan kata lain, harus bersifat kontekstual. Daerah tertentu dengan karakteristik alam dan kultur khas, harus mendapat perhatian khusus sehingga program pembentukan warga negara yang baik bisa efektif. Pendekatan one size fits all sudah saatnya ditinggalkan. Logika berpikir ini hanya cocok untuk dunia industri yang berorientasi pada produksi massal dengan standar dan mekanisme yang seragam. Keseragaman mengingkari hukum alam. Alam bersifat heterogen, demikian juga seharusnya proses pendidikan, baik cara maupun penekanan tujuannya.

Pelajaran kedua yang bisa ditarik dari hasil penelitian ini adalah bahwa untuk daerah-daerah dengan kondisi sarana dan prasarana yang sangat terbatas, guru justru mendapat keleluasaan untuk melakukan "eksperimentasi" dengan mengerahkan segala kemampuan atau kreativitas mereka. Kebanyakan dari mereka (terutama yang ditempatkan di Papua atau di SD Perintis), justru memanfaatkan keterbatasan sarana dan prasarana sekolah dengan cara menyelenggarakan kegiatan belajar di luas ruang kelas dengan memanfaatkan alam sebagai media pembelajaran. Dengan demikian, upaya penyiapan warga negara yang baik melampaui tembok atau pagar (bisa jadi tidak ada tembok atau pagar) sekolah termasuk tuntutan birokratis. Ada yang menekankan pentingnya kedisiplinan (di Malinau), belajar mengoperasikan laptop sebagai pengantar pelatihan Teknologi Informasi (IT) (di Pegunungan Bintang),

Demikian juga dengan pengalaman beberapa subjek penelitian yang mengajar di SD menarik untuk dikaji lebih lanjut. Dengan latar belakang akademik yang dimaksudkan untuk menjadi guru mata pelajaran (baca: guru PPKn), di lapangan mereka terpaksa harus mengajar sebagai guru kelas. Perlunya mata kuliah peminatan yang berorientasi sebagai koordinator pendidikan karakter atau pendidikan moral pada tingkat pendidikan dasar tampaknya perlu mendapat perhatian. Lebih-lebih, pendekatan tematik menjadi kebijakan pemerintah saat ini untuk tingkat 
sekolah dasar. Dengan demikian, Pendidikan Kewarganegaraan bukan merupakan monopoli mata pelajaran PKn, akan tetapi bersifat inter dan lintas disipliner. Hal ini sesuai pendapat dari McCowan, bahwa pendidikan kewarganegaraan dan moral yang efektif harus menggunakan perpaduan baik pembelajaran langsung, praktik terbimbing, observasi dan refleksi (McCowan, 2011).

Dari perspektif lain, upaya pembentukan warga negara yang baik secara garis besar dibedakan menjadi dua, yaitu di sekolah dan di luar sekolah. Hasil penelitian secara internasional telah menemukan, meskipun agak lemah, hubungan antara aktivitas di kelas dan pembentukan komitmen kewargaan dan partisipasinya. Komitmen dan keterlibatan warga merupakan ramuan penting yang dibutuhkan bagi active informed citizens. Sebagai contoh, penelitian J. E. Kahne \& Sporte (2008) menemukan bahwa pengalaman di sekolah yang memfokuskan secara langsung pada isu-isu politik dan kewargaan dan cara bertindak “...are a highly efficacious means offostering commitments to civic participation". Hasil yang sama juga ditemukan oleh Torney-Purta, Amadeo, \& Richardson (2007) dan Gibson \& Levine (2003), diperkuat oleh Saha \& Print (2010) yang menemukan hubungan antara beragam praktik di ruang kelas dengan komitmen terhadap partisipasi kewargaan serta peningkatan partisipasi. Terakhir, temuan dari National Foundation for Educational Research (2009) dinyatakan dalam laporan tahunan ketiga mereka sebagai berikut:

1. Many lessons follow "traditional" formats, teacher, and textbook led rather than discussion and ICT informed.

2. Nonetheless, pupils feel there is a positive climate in which to express opinions and raise issues for consideration.
3. Schools offer a wide range of opportunities for participation, but pupil take-up is limited.

Dengan membandingkan hasil penelitian ini dengan hasil penelitian yang bersifat internasional dapat ditarik kesimpulan bahwa ada semacam kesamaan kecenderungan dalam pembelajaran $\mathrm{PKn}$, yaitu masih dominannya peran guru dalam aktivitas kelas dan penekanannya asih pada bidang pengetahuan dan relatif sedikit pada partisipasi yang bisa meningkatkan keterampilan berpikir kritis siswa. Upaya pembentukan warga negara yang baik dan kompeten merupakan proyek besar yang menuntut kerja sama secara sinergis dari berbagai stakeholders.

\section{SIMPULAN}

Berdasarkan pada hasil penelitian serta pembahasan dengan didukung teori-teori yang relevan, dapat disimpulkan beberapa hal sebagai berikut:

1. Persepsi tentang warga negara yang baik. Secara berurutan dari yang paling penting untuk dikembangkan sebagai ciri warga negara yang baik meliputi: peduli, bertanggung jawab, mandiri, demokratis, kritis, dan sederhana.

2. Pilihan metode mengajar untuk membentuk warga negara yang baik. Hampir semua menggunakan metode ceramah sebagai metode mengajar mereka, meskipun ada beberapa yang menggunakan metode lain, seperti diskusi dan proyek.

3. Hubungan persepsi tentang warga negara yang baik dengan pilihan metode mengajar. Tidak ada hubungan antara persepsi tentang warga negara yang baik dengan pilihan metode mengajar para guru PKn peserta PPG UNY 2016, tetapi 
mereka mempunyai alasan masingmasing yang cukup rasional dengan memperhatikan faktor kontekstual, seperti minimnya sarana dan prasarana serta kondisi budaya dan alamiah setempat.

4. Hambatan yang mereka hadapi di dalam upaya pembentukan warga negara yang baik bersifat internal dan eksternal. Hambatan yang bersifat internal datang dari para guru peserta SM3T dan para siswa. Sedangkan hambatan yang bersifat eksternal berasal dari lingkungan sekolah yang kurang kondusif, khususnya sarana dan prasarana, dalam rangka pembentukan warga negara yang baik.

5. Kondisi yang spesifik di daerah $3 \mathrm{~T}$ tidak membuat mereka patah arang, justru menjadikannya sebagai tantangan untuk melakukan eksperimentasi dan kreativitas mereka di dalam mengajar dalam rangka membentuk warga negara yang baik. Beragam upaya telah mereka lakukan, satu diantaranya dengan "merayu" para guru yang sejatinya berstatus PNS untuk aktif mengajar. Satu hal yang mereka yakini, pembentukan warga negara yang baik tidak bisa diajarkan tetapi diberi teladan, dan mereka siap untuk menjadi teladan itu. A good citizenship is not taught, but caught.

\section{UCAPAN TERIMA KASIH}

Penelitian ini sepenuhnya dibiayai dari Dana DIPA Fakultas Ilmu Sosial Universitas Negeri Yogyakarta. Peneliti mengucapkan terima kasih yang sebesar-besarnya. Tidak lupa juga peneliti haturkan ucapan terima kasih kepada para responden dan pihak lain yang membantu penelitian ini.

\section{DAFTAR PUSTAKA}

Bîrzéa, C. (2000). Education for democratic citizenship: a lifelong learning perspective. Project On "Education for Democratic Citizenship" (Vol. 21). Strasbourg.

Crick, B. (1998). Education for citizenship and the teaching of democracy in schools. Final report of the advisory group on citizenship. London. http://doi.org/10.1177/01447394990190 0204

Davies, I., Shirley, I. G., \& C.Riley. (2003). Good citizenship and educational provision. British Educational Research Journal (Vol. 27). London and New York: Falmer Press and Taylor \& Francis.

De Groot, I. (2011). Why we are not democratic yet: The complexity of developing a democratic attitude. In W. Veugelers (Ed.), Education and humanism: linking autonomy and humanity (pp. 79-94). Roterdam, Boston, Taipe: Springer Science \& Business Media.

Deth, J. W. van. (2013). Citizenship and the civic realities of everyday life. In $\mathrm{M}$. Print \& D. Lange (Eds.), Civic education and competences for engaging citizens in democracies. Roterdam, Boston, Taipe: Sense Publisher.

Gibson, C., \& Levine, P. (2003). The civic mission of schools. New York.

Johnson, L., \& Morris, P. (2010). Towards a framework for critical citizenship education. The Curriculum Journal, 21(1), 77-96. http://doi.org/10.1080/09585170903560 444

Kahne, J. E., \& Sporte, S. E. (2008). Developing citizens: the impact of civic learning opportunities on students' commitment to civic participation. American Educational Research Journal, 45(3), 738-766.

Kahne, J., \& Westheimer, J. (2003). Teaching democracy: what schools need to do. $P h i$ Delta Kappan, 85(1), 34-40, 57-66. 
http://doi.org/10.1177/00317217030850 0109

Keating, A., Kerr, D., Lopes, J., Featherstone, G., \& Benton, T. (2009). Embedding citizenship education in secondary schools in England (2002-08) citizenship education longitudinal study seventh annual report. London. Retrieved from http://dera.ioe.ac.uk/id/eprint/11372\%0 A

McCowan, T. (2011). Rethinking Citizenship Education: a Curriculum for pPrticipatory Democracy. A\&C Black.

Miller, J. P. (2007). The holistic curriculum. Toronto: University of Toronto press.

Mouffe, C. (2005). The return of the political (Vol. 8). Verso.

Print, M., \& Lange, D. (Eds.). (2012). Schools, curriculum and civic education for building democratic citizens. Roterdam, Boston, Taipe: Sense Publishers. http://doi.org/10.1007/97894-6209-167-2

Saha, L. J., \& Print, M. (2010). Student school elections and political engagement: A cradle of democracy? International Journal of Educational Research, 49(1), 22-32.

http://doi.org/http://dx.doi.org/10.1016/j .ijer.2010.05.004
Theiss-morse, E., \& Hibbing, J. R. (2005). Citizenship and Civic Engagement. The Future of Children, 20(1). http://doi.org/10.1146/annurev.polisci.8. 082103.104829

Torney-Purta, J., Amadeo, J., \& Richardson, W. (2007). Civic service among youth in Chile, Denmark, England and the United States: A psychological perspective. In S. M. \& A. McBride (Eds.), Civic Service Worldwide: Impacts and Inquiries (pp. 95-132). Armonk, NY: M.E. Sharpe.

Veldhuis, R. (1997). Education for Democratic Citizenship: dimensions of citizenship, core competences, variables and international activities. Strasbourg.

Veugelers, W. (2007). Creating criticaldemocratic citizenship education: empowering humanity and democracy in dutch education. Compare: A Journal of Comparative and International Education, 37(1), 105-119. http://doi.org/10.1080/03057920601061 893

Veugelers, W. (2011). Education and humanism: Linking Autonomy and Humanity. Springer Science \& Business Media. 